\title{
OPERATIONAL TESTS OF WEAR DYNAMICS OF DRILLS MADE OF LOW-ALLOY HIGH-SPEED HS2-5-1 STEEL
}

\section{BADANIA EKSPLOATACYJNE DYNAMIKI ZUŻYCIA WIERTEK Z NISKOSTOPOWEJ STALI SZYBKOTNĄCEJ HS2-5-1*}

\begin{abstract}
To determine the effect of drill wear on the value of the axial force and cutting torque, a series of durability tests of drills with a diameter of $10 \mathrm{~mm}$ made of high-speed steel HS2-5-1 were carried out. The investigations were conducted during the durability period and at constant values of cutting parameters. The tests were carried out while drilling holes in samples made of C45 steel and EN-GJS-500-7 cast iron. The dynamics of wear on all parts of the drill was also determined. It has been shown that while drilling with different values of cutting parameters, there is a loss of machinability for different values of the wear indicators. While drilling with high cutting speeds and with small feeds, there is a loss of cutting ability in the area of accelerated wear. The application of TiN coating does not change the controlled wear locations. TiN coating only reduces the intensity of wear on the tool flank, which increases the durability of the drill.
\end{abstract}

Keywords: wear dynamics, cutting torque, high-speed steel, drilling, wear.

\begin{abstract}
W celu określenia wpływu zużycia wiertet na wartość sity osiowej oraz momentu skrawania przeprowadzono serię badań trwatościowych wierteł o średnicy $10 \mathrm{~mm}$ wykonanych ze stali szybkotnacej HS2-5-1, przy stałych parametrach skrawania, w czasie jednego przyjętego okresu trwatości. Badania prowadzono podczas obróbki otworów na próbkach ze stali C45 oraz z żeliwa ENGJS-500-7. Określono również dynamikę zużycia na wszystkich częściach skrawających wiertta. Wykazano, że podczas eksploatacji wierteł z różnymi parametrami skrawania, utrata ich skrawności następuje dla różnych wartości wskaźników zużycia. Podczas wiercenia z dużymi prędkościami skrawania i małymi posuwami, utrata skrawności wiertta nastęuje w obszarze przyspieszonego ich zużycia. Naniesienie powłoki TiN nie zmienia kontrolowanych miejsc zużycia a tylko zmniejsza intensywność zużycia na powierzchni przyłożenia, co powoduje wzrost trwatości wiertta.
\end{abstract}

Stowa kluczowe: dynamika zużycia, moment skrawania, stal szybkotnąca, wiercenie, zużycie.

\section{Introduction}

A cutting tool with certain parameters of the initial state starts working at the parameters for which it was designed. With time, in the process of cutting under the influence of mechanical and thermodynamic loads the geometric parameters of the blade change in value. Tool life is characterized by the period of its operation, taking into account the need for sharpening to ensure the state of availability for the job $[1,7]$. All of the quantitative factors of tool life (e.g., probability of reliable operation of the tool, durability, average durability, the density function of durability) can be determined only experimentally on the finished new tool which is characterized by certain indicators of the input state, and based on the statistical observations of tools in operation.

Tribological processes that occur at the contact point of the cutting blade with the workpiece lead to wear and then to a sudden or gradual loss of the tool's cutting ability [18, 24, 26]. Among the symptoms of wear of a blade we can list $[5,11,23,29]$ : changes in the blade geometry, changes in physico-chemical properties due to chemical changes in the surface layer of the material, cracks and chipping of the material of the cutting tool.

Changes in the blade stereometry connected with its wear affect the drilling process [14]. The effect of drill wear on the accuracy of drilling of deep holes was investigated by Wieczorowski and Matuszak [28]. Catastrophic tool wear in tools made of high-speed steel is associated with an increase in the temperature of the cutting part of the tool to a value which causes changes in the basic properties of the tool $[5,29]$. An analysis of the results carried out by Meena and El Mansori [21] showed that high-speed machining of cast iron combined with low feed values causes an increase of the value of cutting forces and the energy of the cut. For a drill with a steady specificity of wear, the temperature can be increased only by the increase of the heat source on the primary tool flanks. From these heat sources in a stage of steady wear, the cutting part of the drill and the drill margin flanks heat up [4]. Under production and laboratory conditions, the characteristic sound of "scratch" is assumed as the beginning of the catastrophic wear [32]. This signal is associated only with tribological changes in the contact surface of the drill and the workpiece. The beginning of this process reflects an increase in the amplitude of the acoustic signal and an increase in friction torque generated at margins of the drill [6]. The degree of wear of the blade is assessed using multiple criteria, which can be divided into four groups [27]: technological, physical, economic and geometric.

According to Pancielejko [22], when determining the wear of an uncoated drill and drills with hard coatings, it is desirable to use a number of wear indicators. Operational tests of twist drills made of high-speed steel HS6-5-2, uncoated and titanium carbonitride Ti (C, $\mathrm{N})$ coated showed that the applied wear factors characterizing drill wear at the corners, at the drill margin and at the chisel edge of a drill characterize well the wear of tested drills. Studies by Liu et al. [20]

(*) Tekst artykułu w polskiej wersji językowej dostępny w elektronicznym wydaniu kwartalnika na stronie www.ein.org.pl 
showed that the most important criterion of wear of the blade should be considered the wear in the corner of the drill.

To ensure suitable durability of drills it is necessary to examine the tool state in specific conditions of its operation and to determine which changed wear factor can be used as a criterion for its evaluation. To determine the effect of wear of the drill during operation on the value of the thrust force and cutting moment, a series of durability tests of drills while drilling holes in samples made of C45 steel and cast iron EN-GJS-500-7 were carried out. The assessment of the dynamics of wear is made according to the maximum linear wear value on all cutting parts of the drill.

\section{Justification of the study}

In order to increase the efficiency and reliability of machining processes it is possible to select cutting parameters for which, in the conditions of normal wear, the required probability of meeting all the quality requirements of the workpiece is ensured [25]. The reliability of the cutting process is conditioned by the period of assumed tool life, cutting forces, and the quality and precision of machined parts $[15,30]$.

In the cutting process, with the passage of time under thermodynamic loading, the geometric parameters of the blade change in value. To ensure efficient machining and the necessary efficiency and to calculate the cost of tool wear, factors that can be used as a criterion of tool wear need to be determined. Therefore, to ensure reliable diagnosis, it is necessary first of all to examine the state of the tool in specific conditions of operation $[6,9]$.

Damage caused by wear of cutting tools is the dominant factor determining the tool life in the optimal operating conditions [16, 17]. As an input criterion for assessing the tool state, a wear indicator should be selected that will clearly describe the change in the geometry and the properties of the tool material that result from the wear of the blade. Simultaneously, the value of the wear indicator should increase monotonically in a zone of normal wear and should allow the realization of accurate measurement [3, 10, 25]. During tool operation, it is very difficult to determine the optimal, economically justified moment to replace the tool. The permissible wear value reported by manufacturers of tools for specific machining conditions may differ from the value of wear that ensures full use of its cutting abilities [11].

Monitoring and surveillance of the blade state can be performed by an operator, or these tasks can be realized automatically. In the case of surveillance of natural wear by the man, the operator monitors the tool state during breaks in machining, based on the assessment of the quality of the workpiece surface obtained after machining, phenomena that accompany the cutting process and observation of the cutting edge geometry. Currently on the market there are systems for monitoring the state of the blades of cutting tools by using direct and indirect methods. They are diverse and have different degrees of effectiveness [13]. A system for monitoring the assumed state of tool wear which takes into account the possibility of its further development for the creation of an integrated adaptive control system of the process to ensure the maximum cutting efficiency is proposed in [2].

\section{Research methodology}

\subsection{Determination of cutting force and cutting torque}

To determine the effect of wear of drills during their operation on the value of the thrust force and cutting torque a series of durability tests was carried out on drills with a diameter $D=10 \mathrm{~mm}$ made of HS2-5-1 high-speed steel, at constant values of cutting parameters during one adopted period of tool life under cut. The investigations were carried out during the processing of initial holes with a diameter $d=4 \mathrm{~mm}$ on specially prepared samples (Fig. 1) made of C45 steel. The thrust force and cutting torque values were measured with a Kistler 9123 CQ05 dynamometer. The dynamometer was set in the drilling machine so that the axis of the drill coincided with the centre of the table of the drilling machine.

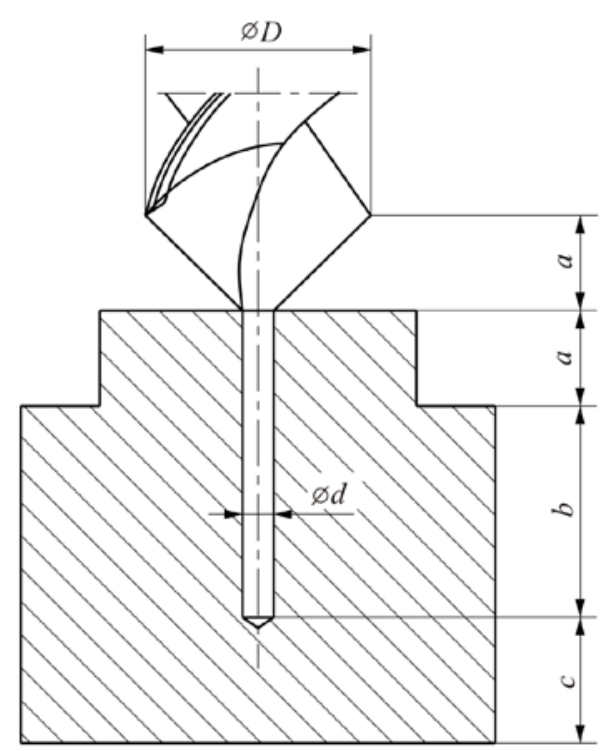

Fig. 1. Sample for the measurement of the machining resistances: a-section of the machine with main cutting edges, $b$-section of the machine with main cutting edges and the drill margins, $c$ - section of the machine with all the cutting edges

The cutting torque value attributable to the margin of the drill is determined as the difference between the torque values recorded at sections $a$ and $b$ (Fig. 1). At section $a$ (Fig. 1) only the lip of the drill participates in the cutting process and at section $b$ (Fig. 1) the lip of the drill and the end cutting edge both participate. Observations of wear were carried out in all cutting parts of the drill. The evaluation of the wear of relevant surfaces was made on the basis of the maximum linear wear values of these surfaces.

\subsection{Investigations of drill wear}

In the literature there is no information on the location of drill wear during the drilling of steel materials that can be taken as an unequivocal criterion for its wear. Therefore, the aim of the research was to determine which controlled area on a drill made of HS2-5-1 steel may constitute such a criterion. Wear parameters which were controlled during machining of samples made of both $\mathrm{C} 45$ steel and cast iron EN-GJS-500-7 are shown in Fig. 2a and Fig. 2b, respectively. Research conducted by Pancielejko [22] has shown that the process of drill wear when machining cast iron has a different character from the case of machining $\mathrm{C} 45$ steel. Often used as the sole factor, $V B$ characterizing the wear of the tool flank during machining of grey cast iron does not reflect the actual degree of wear of drills and can lead to excessive wear of cutting edges in other areas [22]. The different character of tool wear for drilling in steel and cast iron is the reason for developing drills intended only for drilling in cast iron, with a special geometry that ensures the reduction of both blade wear and the cutting force [31].

When machining steel, the tool flank is the main area subjected to wear. Wear of the drill margin causes catastrophic wear of the blade. When machining cast iron, tool flank wear is the reason for taking the drill out of service.

The tests on wear of drills during drilling in steel C45 were carried out in a column drilling machine PK 203, with the following parameters: cutting speed $v_{c}=40 \mathrm{~m} / \mathrm{min}$, feed rate $f=0.06 \mathrm{~mm} / \mathrm{rev}$, as well as $v_{c}=20 \mathrm{~m} / \mathrm{min}$ and $f=0.2 \mathrm{~mm} / \mathrm{rev}$, ensuring the tool life $T_{c} \approx$ 

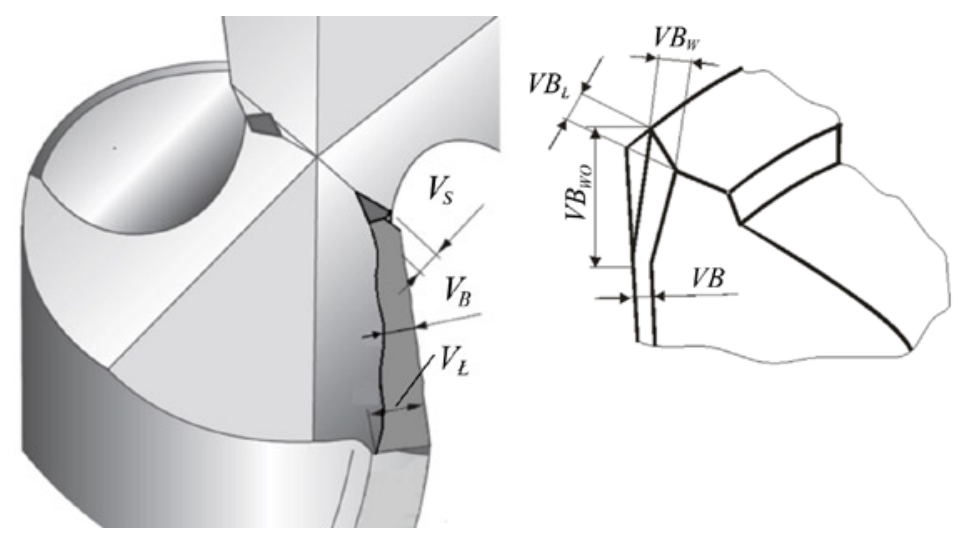

Fig. 2. Areas of wear controlled during durability testing of drills while turning $C 45$ steel (a) and EN-GJS-500-7 cast iron (b): $V_{S}$-wear of flank of chisel edge; $V_{E}$ - wear of drill margin; $V B, V_{B}$-wear of tool flank; $V B_{\ell}-$ wear of drill margin flank; $V B_{W}$-wear of blade corner; $V B_{W O}$ - wear of corner flank [12]

$20 \mathrm{~min}$. Changes in the value of wear of the flank of the chisel edge $V_{S}$, wear of the drill margin $V_{E}$ and wear of the tool flank $V_{B}$ were investigated.

Wear of the drill margin $V_{E}$ was measured by measuring the diameter of the drill at the corners. During machining with the mentioned cutting parameters, ten drills were investigated. This allowed us to obtain statistically significant relationships of the expected values for the analyzed drill wear parameters.

Durability tests of drills during drilling in cast iron EN-GJS-500-7 were carried out at cutting speed $v_{c}=20 \mathrm{~m} / \mathrm{min}$, and three values of feed rate $f=0.1 \mathrm{~mm} / \mathrm{rev}, f=0.3 \mathrm{~mm} / \mathrm{rev}$ and $f=0.4 \mathrm{~mm} / \mathrm{rev}$, ensuring the tool life of $T_{c}=15 \mathrm{~min}$, which corresponded to machining 80-100 holes. In investigations of the tool life during drilling in cast iron, the change in the value of the following factors of tool wear was analyzed: wear of the tool flank $V B$, wear of the drill margin flank $V B_{E}$, wear of the blade corner $V B_{W}$ and wear of the corner flank $V B_{W O}$.

In the investigations a TiN-coated drill and a drill without coating were used. To determine the effect of the TiN coating on the wear of the drill a series of durability tests were carried out. The tool life tests were conducted using specially prepared drills with a diameter $\mathrm{D}=10 \mathrm{~mm}$, on which a TiN coating with a thickness of $0.008 \mathrm{~mm}$ was applied. The studies were conducted at $v_{c}=20 \mathrm{~m} / \mathrm{min}$ and $f=0.2$ $\mathrm{mm} / \mathrm{rev}$, to ensure the tool life of $T_{c}=25 \mathrm{~min}$, which corresponded to machining 100-150 holes.

The chemical composition and the basic mechanical properties of the tested materials are shown in Tables 1 and 2 .

\section{Results and analysis}

\subsection{The effect of wear of HS2-5-1 steel drill on the thrust force and cutting torque}

Changes in the thrust force $F_{f}$ and the cutting torque $M_{c}$ depending on the wear on the lip of a drill are shown in Fig. 3. It should be noted that although on the axis of ordinates only the values of wear of the lip of the drill are marked, the value of the thrust force and cutting torque show the cumulative effect of all places of wear. When catastrophic wear of the drill occurs, an intense increase in the cutting torque is observed (Figs. 3, 4). Thus the cutting torque can be used to determine the time at which catastrophic wear of the drill will appear. The general tendency to increase the thrust force $F_{f}$ and cutting torque $M_{c}$ during drilling operation is observed. However, until catastrophic wear occurs, the values of the thrust force and cutting torque vary differently.

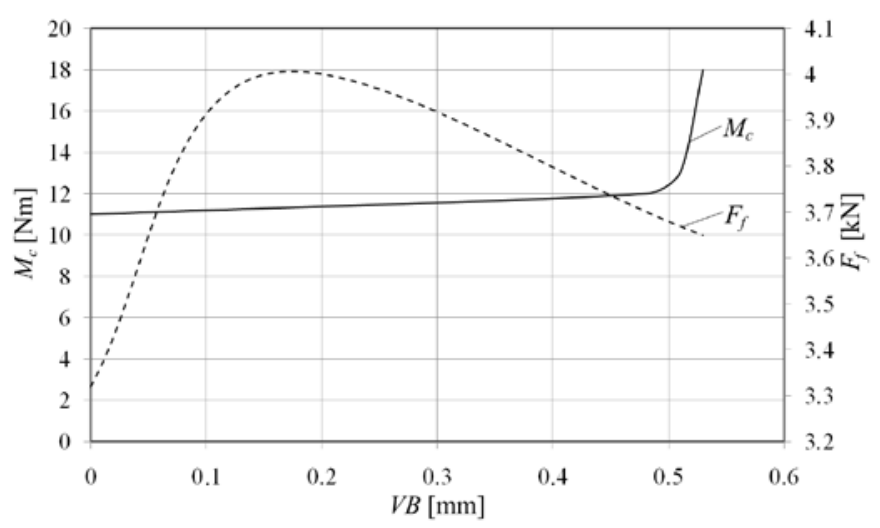

Fig. 3. Dependence of the axial force $F_{f}$ and the cutting torque $M_{c} v$ s. size of wear on the main tool flank $V B$ while turning $C 45$ steel with all parts of the drill at $v_{c}=20 \mathrm{~m} / \mathrm{min}$ and $f=0.2 \mathrm{~mm} / \mathrm{rev}$

The lack of unequivocal correlation between the value of wear of the tool flank and thrust force and cutting torque can be explained by the fact that the drill wears not only on the primary tool flank, but also on the chisel edge of the drill, surfaces adjacent to the chisel edge and on the drill margin. The results of variation in the thrust force $F_{f}$ and cutting torque $M c$ as a function of the wear of the primary tool flank during cutting by using the lips of the drill are presented in Fig. 5.

Increasing the wear of the primary tool flank $V B$ leads to approximately linear increase in the thrust force $F_{f}$ corresponding to the lips of the drill. After reaching a predetermined value of wear, a change in the shape of the chisel edge of the drill occurs, both on the chisel edge of the drill and on the surfaces adjacent to the chisel edge. Therefore, it is not possible to establish the relationship between the thrust force value corresponding to the chisel edge of the drill and the wear of surfaces adjacent to the chisel edge of the drill.

Although the value of the drill margin wear increases slightly during operation of the drill, a significant increase

Table 2. Basic mechanical properties of the tested materials [8]

\begin{tabular}{|c|c|c|c|c||}
\hline Material & $\begin{array}{c}\text { Yield stress } \\
\mathrm{R}_{\mathrm{e}} \\
{[\mathrm{MPa}]}\end{array}$ & $\begin{array}{c}\text { Tensile strength } \\
\mathrm{R}_{\mathrm{m}} \\
{[\mathrm{MPa}]}\end{array}$ & $\begin{array}{c}\text { Elongation } \\
\mathrm{A}_{5} \\
{[\%]}\end{array}$ & $\begin{array}{c}\text { Hardness } \\
\mathrm{HB}\end{array}$ \\
\hline C45 & 420 & 670 & 16 & 241 \\
\hline EN-GJS-500-7 & 320 & 500 & 7 & $170-230$ \\
\hline
\end{tabular}
in cutting torque attributable to the primary tool flanks is observed. As the drill wear increases, the amount of heat released in the cutting zone and thermal deformation of the workpiece caused by this phenomenon also increases. With increase of the drill wear, the drilled holes deform in such a way that their diameters decrease [11]. Once the deforma- 


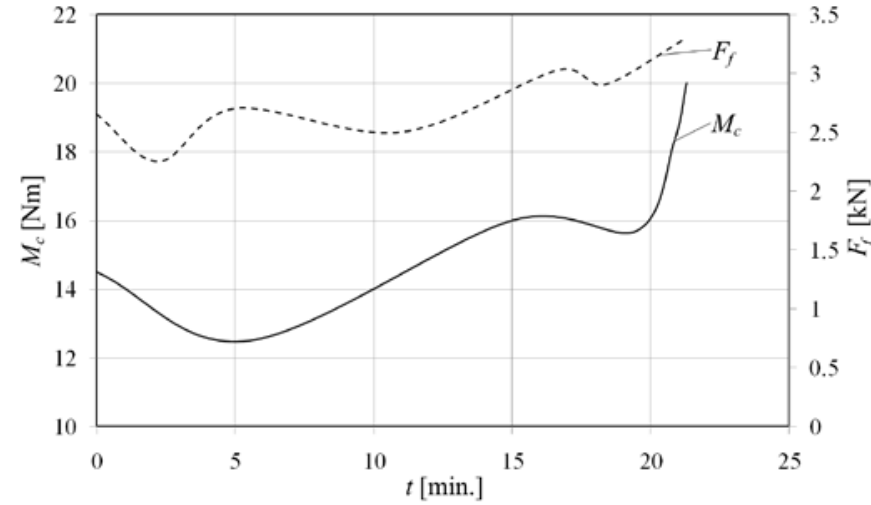

Fig. 4. Effect of machining time ton the value of the axial force $F_{f}$, the cutting torque $M_{c}$ while turning $C 45$ steel at $v_{c}=20 \mathrm{~m} / \mathrm{min}$ and $f=0.2 \mathrm{~mm} /$ rev

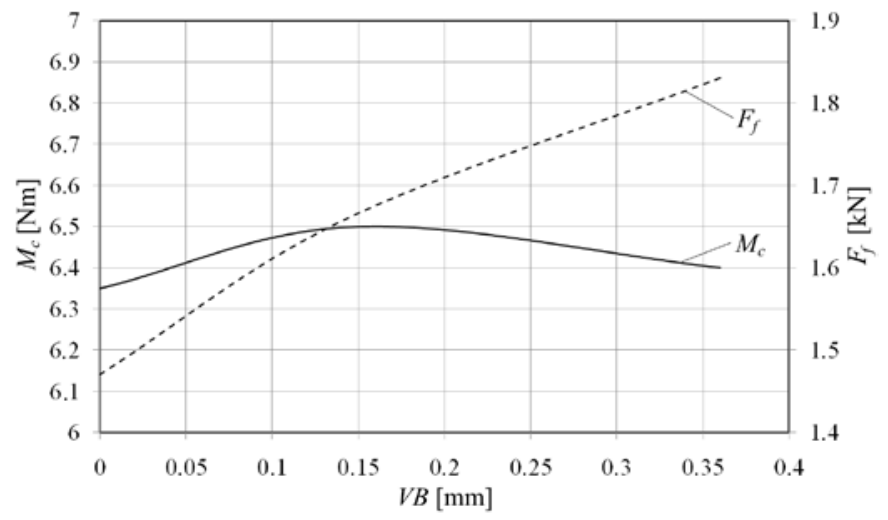

Fig. 5. Dependence of the axial force $F_{f}$ and the cutting torque $M_{c} v s$ wear of the main tool flank VB while turning with main cutting edges; cutting parameters: $v_{c}=20 \mathrm{~m} / \mathrm{min}$ and $f=0.2 \mathrm{~mm} / \mathrm{rev}$

tion exceeds the clearance arising as a result of the reverse drill taper, the machined surface of the hole will cause a change in the contact area on the drill margins, their wear and the occurrence of catastrophic drill wear.

The observed values of the drill margin wear are insignificant, and therefore the chisel edge of a drill does not participate in the cutting process. It can be assumed that the increase in cutting torque attributable to the drill margin is caused by wear on the primary tool flanks.

\subsection{Drill wear while drilling $\mathrm{C} 45$ steel}

Changes in the value of the wear factors of drills made of HS25-1 steel without coating while processing $\mathrm{C} 45$ steel are shown in Figs. 6 and 7. The tool flank wear $V B$ occurs in the case of both the cutting parameters applied. In the period of tool lapping, intensive wear of the chisel edge of the drill is observed. The wear of the drill margin is almost imperceptible, until the moment when catastrophic wear occurs.

The wear of both the tool flank $V_{B}$ and the flank of the chisel edge $V_{S}$ increases monotonically in the period of normal wear. None of these parameters reflects the moment when catastrophic wear occurs. The values of the $V_{B}$ and $V_{S}$ parameters at the moment of catastrophic wear depend on the values of the cutting parameters. The wear of the tool flank $V_{B}$ at the moment of catastrophic wear at $v_{c}=40 \mathrm{~m} / \mathrm{min}$ and $f=0.6 \mathrm{~mm} / \mathrm{rev}$ is $0.2 \mathrm{~mm}$ (Fig. 6), while at $v_{c}=20 \mathrm{~m} / \mathrm{min}$ and $f=0.2$ $\mathrm{mm} / \mathrm{rev}$ it is about $0.55 \mathrm{~mm}$ (Fig. 7).

The results of investigations of the TiN-coated drills (Fig. 8) suggest that their wear is the same as drills without the coating, but the intensity of wear in controlled areas is smaller, which causes an

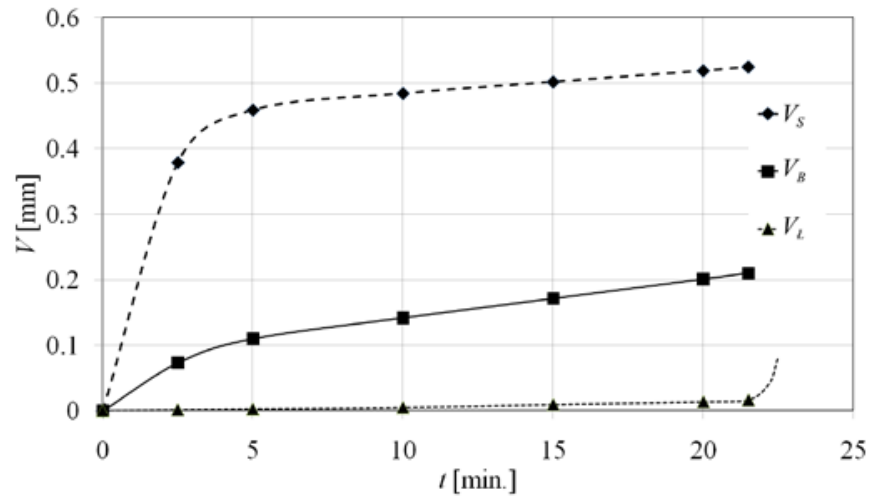

Fig. 6. Dynamics of the variation of the wear parameters while drilling $C 45$ steel at $v_{c}=40 \mathrm{~m} / \mathrm{min}$ and $f=0.06 \mathrm{~mm} / \mathrm{rev}$

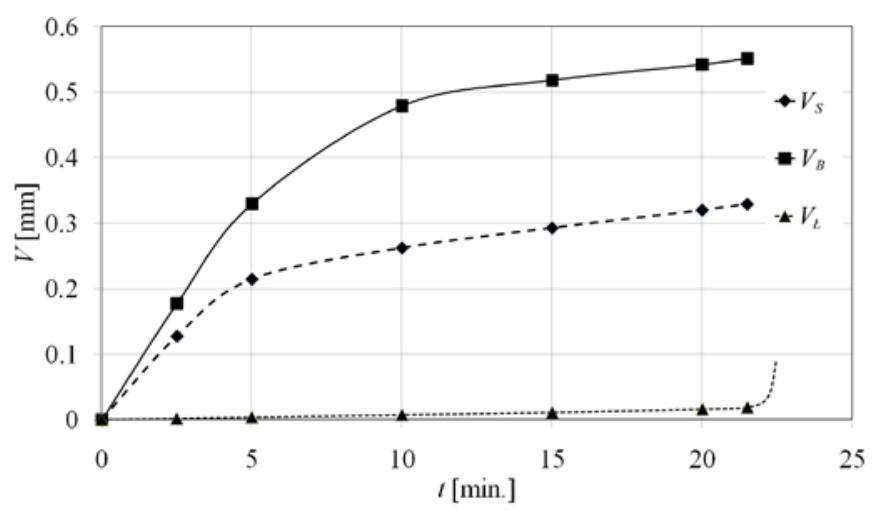

Fig. 7. Dynamics of the variation of the wear parameters while drilling C45 steel at $v_{c}=20 \mathrm{~m} / \mathrm{min}$ and $f=0.2 \mathrm{~mm} / \mathrm{rev}$

increase of the tool life. Thus, applying the TiN coating does not change the areas of wear but only reduces the wear intensity.

The specificity of the wear of drills made of HS2-5-1 steel while drilling C45 steel primarily consists in the wear of the tool flank, and the loss of their cutting ability (catastrophic wear) occurs unexpectedly on the drill margin $V_{t}$. To prevent such unexpected wear it is necessary to know, on the basis of investigations, the value of permissible wear on the tool flank of the drill. The values of pressure during the drilling are the same order as in the case of friction welding, and lead to catastrophic wear of the drill margin. It is well known $[10,25]$ that the permissible value of the wear of the tool flank from which the loss of cutting ability of the drill begins depends on the cutting conditions and above all on the cutting parameters. It is not possible to determine the permissible value of wear $V_{B}$, from which catastrophic wear of the drill margin starts. This can be explained by the fact that the value of

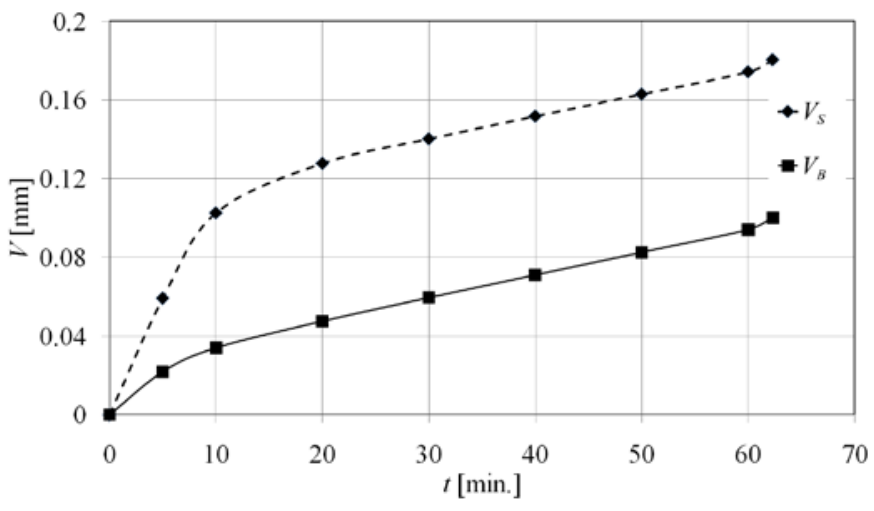

Fig. 8. Dynamics of the variation of the wear parameters while drilling $C 45$ steel using TiN coated drill at $v_{c}=20 \mathrm{~m} / \mathrm{min}$ and $f=0.2 \mathrm{~mm} / \mathrm{rev}$ 
deformation of the drilled holes under the influence of the temperature, leading to catastrophic drill wear, depends on many parameters, often mutually correlated [12].

\subsection{Drill wear while drilling cast iron EN-GJS-500-7}

An increase of the feed value from the value $f=0.1 \mathrm{~mm} / \mathrm{rev}$ to $f=$ $0.4 \mathrm{~mm} / \mathrm{rev}$ causes an approximately two-fold increase in the values of $V B_{W O}, V B_{W}$ and $V B_{E}$, parameters at which the period of normal wear of the drill begins (Figs. 9-11). Taking into account all the feed values, the zone of normal wear starts in the range of parameter values: $V B=0.07-0.1 \mathrm{~mm} V B_{£}=0.15-0.3 \mathrm{~mm} V B_{W}=0.2-0.46 \mathrm{~mm}$ and $V B_{W O}=0.3-0.54 \mathrm{~mm}$. In the period of normal wear of controlled areas of the drill blade there is a monotonic increase in the value of all the tested parameters (Figs. 9-12). The value of feed has a significant impact on the moment when a fast increase of the wear of the blade corner $V B_{W O}$ begins. The fast increase in the value of the parameter $V B_{W O}$ during drilling at feed $f=0.1 \mathrm{~mm} / \mathrm{rev}$ exists after making approximately $n=100$ holes. After a three-fold increase of the feed rates, a fast increase of the wear of the corner flank occurs at the parameter value $V B_{W O}=0.7 \mathrm{~mm}$ after making 40 holes. This leads to breaking of the drill margin, preventing further control of the wear of the blade on the corner flank.

The intensification of the wear process means that after a certain time the wear $V B_{W}$ encompasses the whole width of the drill margin. Under these conditions, after breaking the reference lines, measurement of the wear of the drill margin $V B_{E}$ is impossible (Fig. 11). A rapid increase in the wear of the blade corner $V B_{W}$ does not have a significant effect on the change of values of other wear parameters. Their values increase monotonically. Only the value of the $V B$ factor obtained during the drilling at feed $f=0.1 \mathrm{~mm} / \mathrm{rev}$ for the whole period of normal wear remains stable (Fig. 12). This means that there is no loss of the cutting ability of the blade and the rapid increasing

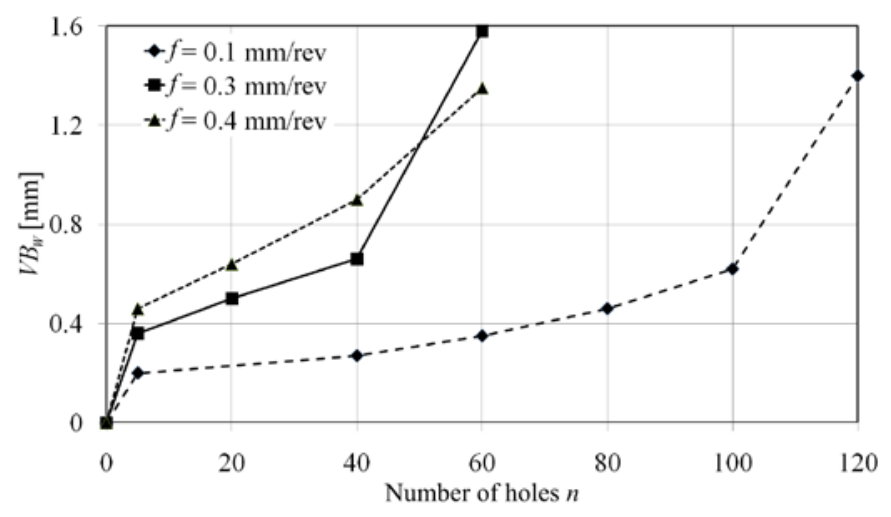

Fig. 9. Dynamics of the wear of the blade corner $V B_{W}$ at $v_{c}=20 \mathrm{~m} / \mathrm{min}$

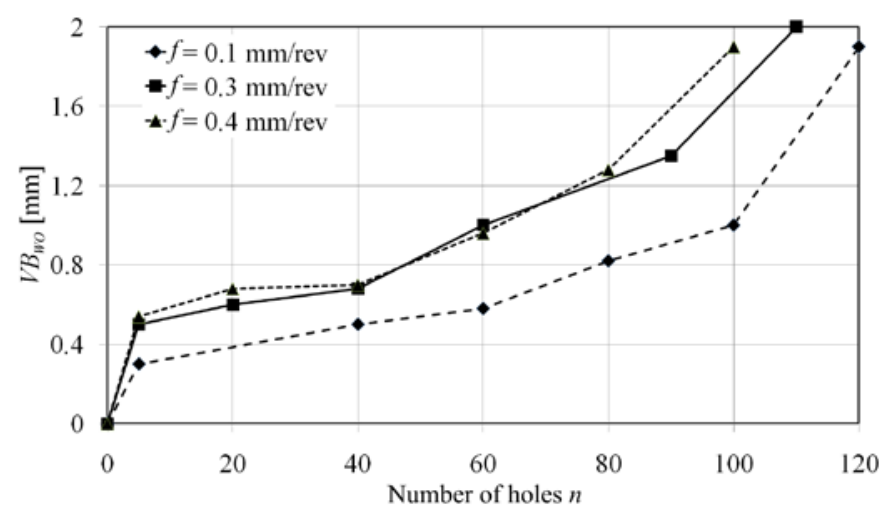

Fig. 10. Dynamics of the wear of the corner flank $V B_{W O}$ at $v_{c}=20 \mathrm{~m} / \mathrm{min}$

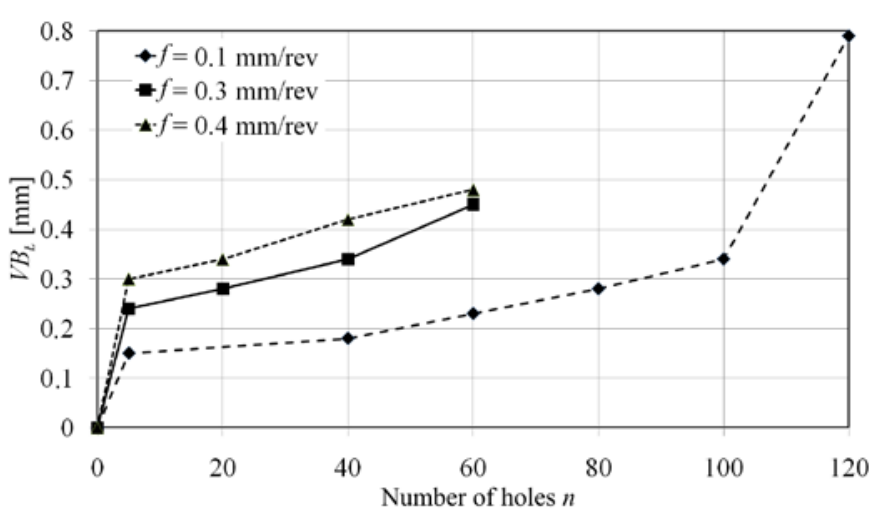

Fig. 11. Dynamics of the wear of drill margin flank $V B_{E}$ at $v_{c}=20 \mathrm{~m} / \mathrm{min}$

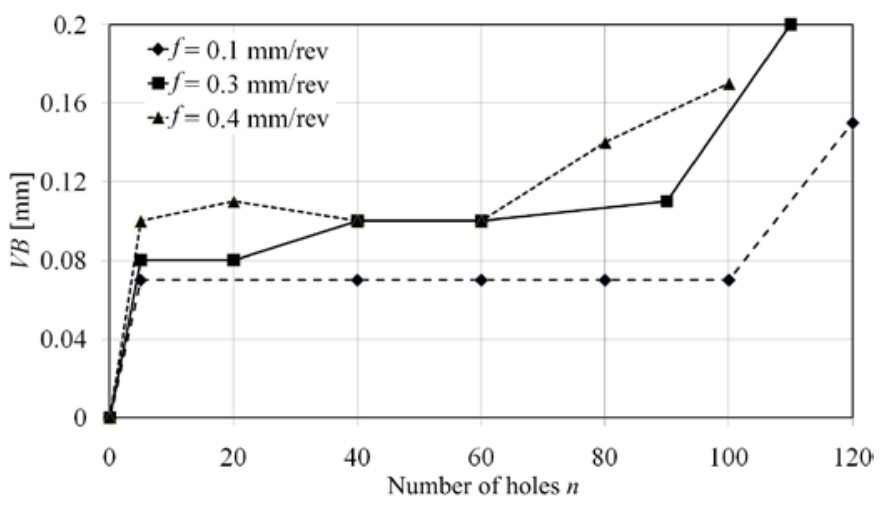

Fig. 12. Dynamics of the wear of the tool flank $V B$ at $v_{c}=20 \mathrm{~m} / \mathrm{min}$

of the wear of the blade corner cannot be considered as the beginning of accelerated wear.

When operating the drill, the rapid increase in the value of the $V B_{W}$ factor does not cause the loss of the cutting ability of the blade. Then increased intensity of the blade corner occurs, and thus the drill wear moves from the first to the second phase of normal wear. Loss of the cutting ability occurs as a result of the intensification of the wear of the corner flank. The moment when the cutting ability is lost depends on the feed and occurs after making about 80-100 holes (Fig. 10).

The character of the variation of the wear of the corner flank $V B_{W O}$ at the first (to 40 holes) and second (after 40 holes) phases of normal wear changes slightly (Fig. 10). The zone of accelerated wear when working at feeds $f=0.3 \mathrm{~mm} / \mathrm{rev}$ and $f=0.4 \mathrm{~mm} / \mathrm{rev}$ begins after the realization of 80 holes at the $V B_{W O}$ value of about $1.25 \mathrm{~mm}$. At the feed of $0.1 \mathrm{~mm} / \mathrm{rev}$ the value of the $V B_{W O}$ factor is about $1 \mathrm{~mm}$. During machining of 40-80 holes the values of the blade corner wear and wear of the drill margin flank change slightly (Figs. 9 and 11).

\section{Conclusions}

In catastrophic drill wear an intense increase in the cutting torque is observed. So the cutting moment can be used as a diagnostic criterion for determining the moment at which catastrophic wear occurs.

The application of a TiN coating does not change the places on the drill where wear occurs but only reduces the intensity of the wear of the tool flank. It allows the tool life of the drill to be increased.

In the case of drilling C45 steel there is a lack of such places of wear that can be used as a criterion of drill wear before its cutting ability is lost (catastrophic wear). In the period of tool lapping, intensive wear of the chisel edge of the drill is observed. Wear of the drill margin is almost imperceptible, until the moment when catastrophic wear occurs. 
An increase in the feed value from the value $f=0.1 \mathrm{~mm} / \mathrm{rev}$ to $f=$ $0.4 \mathrm{~mm} / \mathrm{rev}$ causes an approximately two-fold increase in the values of parameters $V B_{W O}, V B_{W}$ and $V B_{E}$, at which the period of normal wear of the drill begins. In the period of normal wear of controlled areas of the drill blade there is a monotonic increase in the value of all tested parameters.

When drilling holes in samples of cast iron EN-GJS-500-7, a rapid increase in the wear of the blade corner $V B_{W}$ does not have a significant effect on changing the values of other wear parameters. Their values increase monotonically. This means that no loss of the blade's cutting ability occurs and the rapid increasing of the wear of the blade corner cannot be considered as the beginning of accelerated wear. When operating the drill, the rapid increase in the value of the $V B_{W}$ factor does not cause the loss of the blade's cutting ability. Then increased intensity of the blade corner occurs, and thus the drill wear goes from the first to the second phase of normal wear.

\section{References}

1. Cichosz P. Narzędzia skrawające. Warszawa: WNT, 2006.

2. Baldan A, Cuppini D, D'errico G, Rutelli G. Tool wear monitoring based on cutting power measurement. Wear 1990; 139: 303-311, http:// dx.doi.org/10.1016/0043-1648(90)90052-C.

3. Czechowski K, Profeska-Filip I, Fedaczyński A. PVD coatings on ceramic materials cutting inserted. Surface Engineering 2005 ; 2 : $19-24$.

4. Dolinšek S. Work-hardening in the drilling of austenitic stainless steels. Journal of Materials Processing Technology 2003; 133: 63-70, http:// dx.doi.org/10.1016/S0924-0136(02)00245-5.

5. Gawlik J. Prognozowanie stanu zużycia ostrzy narzędzi w procesie skrawania. Kraków: Wydawnictwo Politechniki Krakowskiej, 1988.

6. Gómez M P, Hey A M, Ruzzante J E, D'Attellis C E. Tool wear evaluation in drilling by acoustic emission. Physics Procedia 2010; 3: 819825, http://dx.doi.org/10.1016/j.phpro.2010.01.105.

7. Grzesik W, Podstawy skrawania materiałów metalowych. Warszawa: WNT, 1998.

8. Grzesik W, Żak K. Investigations of surface textures produced by oblique machining of different workpiece materials. Archives of Materials Science and Engineering 2011; 52:46-53.

9. Huang B W, Kuang J H, Yu P P. Effect of crack on drilling vibration. Journal of Sound and Vibration 2009; 322: 1100-1116, http://dx.doi. org/10.1016/j.jsv.2008.11.048.

10. Jaworski J. Development tendency of cutting tool materials. Przegląd Mechaniczny 2005; 11: 33-36.

11. Jaworski J, Trzepieciński T. Możliwości zapewnienia jakościowego wykonania narzędzi z oszczędnościowej stali szybkotnącej. Rzeszów: Oficyna Wydawnicza Politechniki Rzeszowskiej, 2014.

12. Jaworski J, Kluz R, Trzepieciński T. Wpływ parametrów obróbki na miejsce powstawania zużycia i intensywność procesu zużywania wierteł. Tribologia 2014; 45: 81-90.

13. Jemielniak K. Automatyczna diagnostyka stanu narzędzia i procesu skrawaniem. Warszawa: Oficyna Wydawnicza Politechniki Warszawskiej, 2002.

14. Jurko J, Berdis A., Gecák J, Nemcova J. Study of changes the tool wear of the cutting tool part of a cast iron GTW 35-04 while drilling. Applied Mechanics and Materials 2013; 404: 82-85, http://dx.doi.org/10.4028/www.scientific.net/AMM.404.82.

15. Kilickap E. Optimization of cutting parameters on delamination based on Taguchi method while drilling of GFRP composite, Expert Systems with Applications 2010; 37: 6116-6122, http://dx.doi.org/10.1016/j.eswa.2010.02.023.

16. Królczyk G M, Niesłonny P, Legutko S. Determination of tool life and research wear while duplex stainless steel turning. Archives of Civil and Mechanical Engineering 2015; 15: 347-354, http://dx.doi.org/10.1016/j.acme.2014.05.001.

17. Królczyk G, Gajek M, Legutko S. Predicting the tool life in the dry machining of duplex stainless steel. Eksploatacja i Niezawodnosc Maintenance and Reliability 2013; 15: 62-65.

18. Kuczmaszewski J, Pieśko P. Wear of milling cutters resulting from high silicon aluminium alloy cast AlSi21CuNi machining. Eksploatacja i Niezawodnosc - Maintenance and Reliability 2014; 16: 37-41.

19. Leppert T, Peng R L. Surface residual stresses in dry turning of 0.45\% C steel. International Centre for Diffraction Data 2009, 2009: 304311.

20. Liu H S, Lee B Y, Tarng Y S. In-process prediction of corner wear in drilling operations. Journal of Materials Processing Technology 2000; 101: 152-158, http://dx.doi.org/10.1016/S0924-0136(00)00434-9.

21. Meena A, El Mansori M. Drilling performance of green austempered ductile iron (ADI) grade produced by novel manufacturing technology. International Journal of Advanced Manufacturing Technology 2012; 59: 9-19, http://dx.doi.org/10.1007/s00170-011-3469-1.

22. Pancielejko M. Analiza mechanizmów zużycia wierteł ze stali HS6-5-2 z powłokami Ti(C, N) wytworzonymi metodą PVD, po badaniach eksploatacyjnych. Inżynieria Materiałowa 2010; 31: 1147-1152.

23. Przestacki D, Jankowiak M. Surface roughness analysis after laser assisted machining of hard to cut materials. Journal of Physics: Conference Series 2014: 483: 012019, http://dx.doi.org/10.1088/1742-6596/483/1/012019.

24. Semotiuk L. An analysis of the operational characteristics of innovative tool structures used in high speed rough milling processes. Eksploatacja i Niezawodnosc - Maintenance and Reliability 2009; 11: 46-53.

25. Sinopalnikov W A, Grigoriev S N. Reliability and diagnosis of technological systems. Moscow: MGU Stankin, 2003.

26. Twardowski P, Legutko S, Krolczyk G M, Hloch S. Investigation of wear and tool life of coated carbide and cubic boron nitride cutting tools in high speed milling. Advances in Mechanical Engineering 2015; 7: 1-9, http://dx.doi.org/10.1177/1687814015590216.

27. WartaczA, Świć A, Zubrzycki J. Zużycie ostrza narzędzia, a zmiana parametrów toczenia w kolejnych zabiegach. Eksploatacja i Niezawodnosc - Maintenance and Reliability 2004; 4: 58-61.

28. Wieczorowski K, Matuszak A. Wpływ zużycia wiertła na dokładność wiercenia głębokich otworów. Archiwum Technologii Maszyn i Automatyzacji 1997; 17: 67-71.

29. Yan J, Murakami Y, Davim J P. Tool design, tool wear and tool life, [in:] K. Cheng (ed.), Machining dynamics. Fundamentals, applications and practices. London: Springer-Verlag, 2009: 117-149, http://dx.doi.org/10.1007/978-1-84628-368-0_5. 
30. Zabel A, Heilmann M. Deep hole drilling using tools with small diameters process analysis and process design, CIRP Annals - Manufacturing Technology 2012; 61: 111-114.

31. Zheng X, Zhang H, Xue K, Chen M, Zhang Y, Optimization of twist drill's geometry for cast iron. Key Enginnering Materials 2010; 431-432: 555-558, http://dx.doi.org/10.4028/www.scientific.net/KEM.431-432.555/

32. Zoriktuev V T, Nikitin Y A, Sidorov A S. Monitoring and prediction of cutting-tool wear. Russian Engineering Research 2008 ; 28 : 88-91.

Jan JAWORSKI
Rafał KLUZ
Department of Manufacturing and Production Engineering
Rzeszow University of Technology
Al. Powstańców Warszawy 12, 35-959 Rzeszów
Tomasz TRZEPIECIŃSKI
Department of Materials Forming and Processing
Rzeszow University of Technology
Al. Powstańców Warszawy 12, 35-959 Rzeszów
E-mails: jjktmiop@prz.edu.pl, rkktmiop@prz.edu.pl,
tomtrz@prz.edu.pl

